\title{
Four Cases of Brain Stem Lesion Presented with Central Sleep Apnea Syndrome
}

\author{
Santral Uyku Apne Sendromu ile Prezente Olan Dört Beyin Sapı Lezyonu Olgusu
}

\author{
Nergiz Hüseyinoğlu, Serkan Özben, Hilal Șafak Șanıvar \\ Department of Neurology, Kafkeas University School of Medicine, Kars, Turkey
}

\begin{abstract}
Central sleep apnea syndrome is a disorder characterized by the recurrent episodes of apnea during sleep resulting from transient pause of ventilatory effort. Various cardiologic and metabolic causes of the central sleep apnea have been described. In addition, various neurological diseases affecting brainstem have been implicated in the development of the sleep apnea. In this report, we presented four patients with central sleep apnea syndrome and normal neurologic, otorhinolaryngologic and cardiovascular findings. For a further and detailed neurologic examination we performed a magnetic resonance imaging examination and eventually detected pathological findings associated with arachnoid cyst and meningiomas.
\end{abstract}

Key words: brain stem; central sleep apnea; magnetic resonance imaging; polysomnography

\section{ÖZET}

Santral uyku apne sendromu, uyku sırasında solunum çabasının yokluğu nedeniyle olușan tekrarlayıcı apneler ile karakterize bir hastalıktır. Santral uyku apnesinin çeșitli kardiyolojik ve metabolik nedenleri tanımlanmıștır. Beyin sapını etkileyen farkı nörolojik hastalıklar da santral uyku apnesinin gelișiminden sorumlu tutulmuștur. Burada nörolojik, kulak- burun- boğaz ve kardiyolojik muayeneleri normal olan, santral uyku apne sendromlu dört hastayı sunduk. Daha ileri ve ayrıntılı nörolojik inceleme için beyin manyetik rezonans görüntüleme incelemesi yaptık ve sonunda beyin sapında santral apnelere neden olabilecek araknoid kist ve menenjiomlar saptadık.

Anahtar kelimeler: beyin sapl; santral uyku apnesi; manyetik rezonans görüntüleme; polysomnografi

Nergiz Hüseyinoğlu, Kafkas Üniversitesi Thp Fakültesi, Nöroloji Anabilim Dall, Kars, Türkiye Tel.05058119172 Email.nergizabbas@gmail.com

Gelis Taribi: 19.12.2012 • Kabul Taribi: 18.03.2013

\section{Introduction}

Central sleep apnea (CSA) is a neurological disorder characterized by the recurrent episodes of apnea during sleep resulting from transient pause of ventilatory effort. Central apnea is traditionally defined as the absence airflow with a lack of inspiratory effort lasting at least 10 seconds $^{1}$. CSA is seen in less than $10 \%$ of patients with sleep apnea and the usual coexistent events are obstructive.

Various causes of CSA have been described. However, in some cases etio-pathogenesis has not been established ${ }^{1}$. In order to understand the normal mechanisms regulating the ventilation during sleep and wakefulness, the patho-physiology of the CSA must be lightened. All possible underlying causes of CSA should be investigated during the care of patients with the disorder.

Ventilation during sleep is controlled by complex mechanisms, in where the brain stem and its pathways play an important role. The brain stem is a primary generator for rhythmic breathing pattern during sleep and wakefulness ${ }^{2}$. Therefore, various neurological diseases affecting brain stem have been implicated in the development of sleep apnea. Certain pathological conditions, such as hemorrhage, infarction, tumors, brain stem encephalitis, trauma, Arnold-Chiari malformations, damaging the area may result in breathe dysrhythmias, mostly the central sleep apneas, during sleep ${ }^{3,4}$.

In this report, we presented four patients with complaints of snoring, hypersomnolence, frequent nocturnal wakening and witnessed apneas during sleep. After a full night polysomnographic recording performed between the dates January 2011 and March 2012, we mostly detected central apneas coexisting 
with less frequent obstructive apneas. Sleep disordered breathe events were scored manually according to the American Academy of Sleep Medicine criteria $^{5}$.

The patients were investigated for otorhinolaryngologic, cardiovascular and metabolic disorders; however there was not any remarkable finding. Neurological examination was also normal. For a further and detailed neurologic examination we performed a magnetic resonance imaging examination and eventually detected pathological findings associated with arachnoid cyst and meningiomas.

\section{Case 1}

After a polysomnographic recording a 46-year-old male patient with a body mass index (BMI) of 22.5 $\mathrm{kg} / \mathrm{m}^{2}$ was diagnosed with CSA. He had an apnea/ hypopnea index (AHI) of $18.7 / \mathrm{h}$ and central apnea index of $12.4 / \mathrm{h}$. MRI examination revealed an arachnoid cyst on the brain stem, caudal to the right 7,8 and $9^{\text {th }}$ cranial nerves (Figure 1). The neurosurgeons offered a clinical observation without surgery. We applied a continuous positive airway

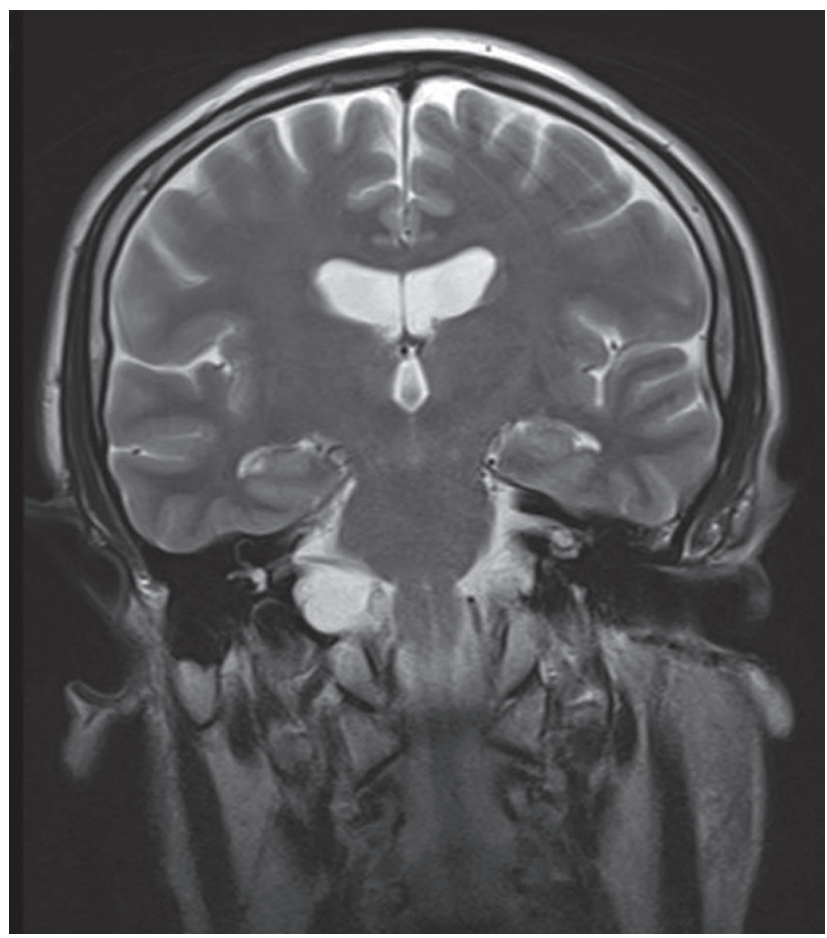

Figure 1. A coronal T2 weighted MRI image of a hyperintense lesion at the right pons and bulbus. pressure (CPAP) therapy and observed the clinical and polysomnographic improvement of the symptoms.

\section{Case 2}

A 75-year-old female patient with a BMI of 27.8 $\mathrm{kg} / \mathrm{m}^{2}$ was diagnosed with CSA. She had an AHI of $41.6 / \mathrm{h}$ and central apnea index of $35.9 / \mathrm{h}$ after a polysomnographic recording (Figure 2). Except from a well regulated hypertension, her medical history was unremarkable. A MRI examination revealed a meningioma on the right side of bulbus (Figure 3). The neurosurgeons offered surgery for the intracranial mass, however the patient refused surgery. Now she is under symptomatic medication with acetozolamide $250 \mathrm{mg}$ twice a day. The symptom of daytime sleepiness has improved. CPAP therapy was not started due to the possible risks of complications such as the complex central apnea or intracranial hypertension.

\section{Case 3}

A 56-year-old female patient with a BMI of 25.6 $\mathrm{kg} / \mathrm{m}^{2}$ was diagnosed with CSA. She had an AHI of $16.9 / \mathrm{h}$ and central apnea index of $11.5 / \mathrm{h}$ after a polysomnographic recording. In the examination of a computerized tomography (CT) (Figure 4) and a contrast enhanced MRI, we detected a mass with the dimensions of $15 \times 10 \mathrm{~mm}$ suggesting a meningioma on the left side of the lower bulbus. Surgical intervention was suggested, however the patient refused surgery. She is under periodic follow-up.

\section{Case 4}

A 57-year-old female patient with a BMI of 24.3 $\mathrm{kg} / \mathrm{m}^{2}$ was diagnosed with CSA. She had an AHI of $23.7 / \mathrm{h}$ and central apnea index of $13.7 / \mathrm{h}$ after a polysomnographic recording. In the MRI examination, a meningioma with $43 \times 33 \times 23 \mathrm{~mm}$ dimensions was detected at the right cerebellopontine angle (Figure 5). Surgical removal of the mass was indicated and the patient was referred to another center.

\section{Discussion}

Advancements in the electrophysiological, radiological, neuroanatomical and neurochemical techniques have provided sufficient information on the organization of respiratory rhythmogenesis, control of 


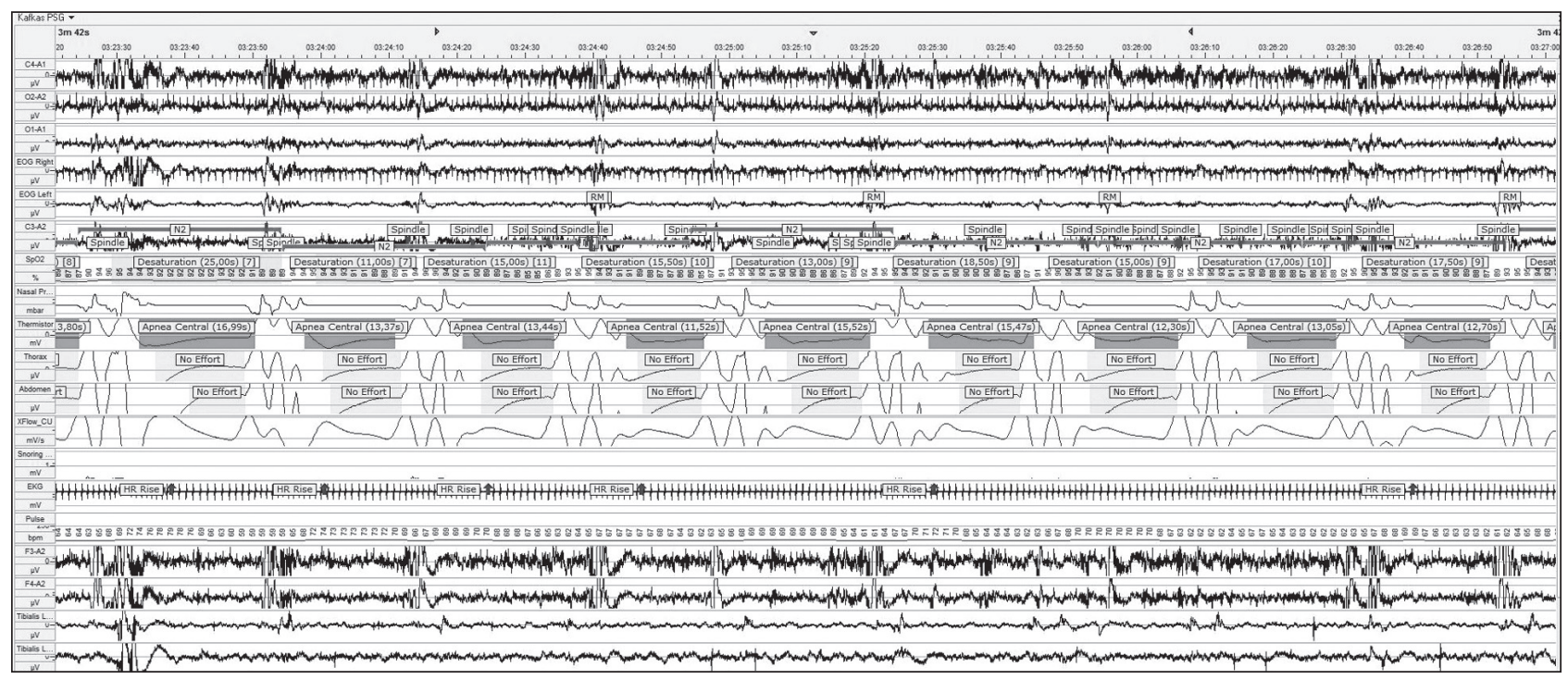

Figure 2. A polysomnographic recording showing central sleep apnea.

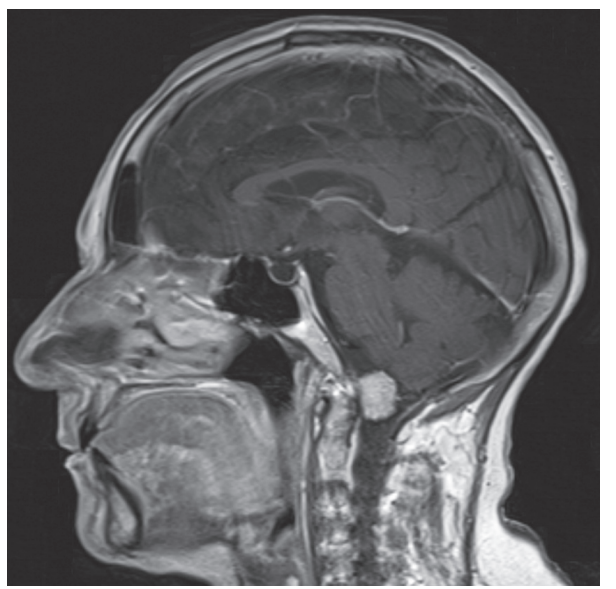

Figure 3. A sagittal contrast enhanced T1 weighted MRI image of a diffuse contrast enhanced lesion at the right the left lower bulbus. lower bulbus.

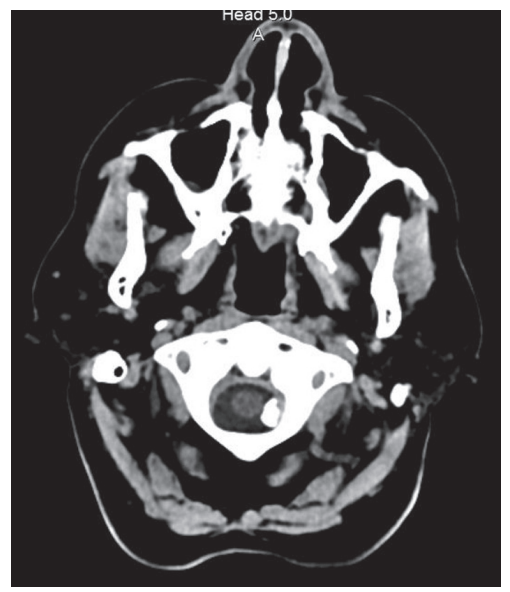

Figure 4. A CT image of a hyperdense lesion at 
In our patients, although we could not find any abnormality in their physical and neurological examination, we detected that the CSAs were more dominant than the obstructive apneas. These findings led us to the suspicion of subclinical brain stem pathology. All patients were investigated for other causes of the CSA, however no cardiovascular, renal or metabolic diseases were detected. All four patients were diagnosed with brain stem pathologies with the help of MRI and CT. The occult pathologies of the patients were slowly growing masses of arachnoid cyst and meningioma. Probably the characteristic of the slow growth and progression of the lesions resulted in sleep apnea related symptoms instead of localized neurologic deficits. From this point of view, a brain imaging examination should be offered in the patients with a predominant CSA, even if their clinical and physical examinations are normal.

\section{References}

1. Guilleminault C, van den Hoed J, Mitler MM. Clinical overview of the sleep apnea syndromes. In: Guilleminault C, Dement W, editors. Sleep apnea syndromes. New York: Alan R Liss; 1978: 1-12.

2. Bianchi AL, Denavit- Saubie M, Champagnat J. Central control of breathing in mammals: an overview. Respir Physiol Neurobiol 2004; 143: 115-25.

3. Nogues MA, Roncoroni AJ, Benarroch E. Breathing control in neurological diseases. Clin Auton Res 2002; 12: 440-9.

4. Tsara V, Serasli E, Kimiskidis V, et al. Acute respiratory failure and sleep-disordered breathing in Arnold-Chiari malformation. Clin Neurol Neurosurg 2005; 107:521-4.

5. Iber C, Ancoli-Israel S, Chesson A, et al. for the American Academy of Sleep Medicine. The American Academy of Sleep Medicine (AASM) Manual for the Scoring of Sleep and Associated Events: Rules, Terminology and Technical Specifications (1st edition). Westchester, IL: American Academy of Sleep Medicine; 2007. 